\title{
Deleterious FANCE Gene Mutation
}

National Cancer Institute

\section{Source}

National Cancer Institute. Deleterious FANCE Gene Mutation. NCI Thesaurus. Code C150152.

A change in the nucleotide sequence of the FANCE gene that is associated with increased risk of disease. 